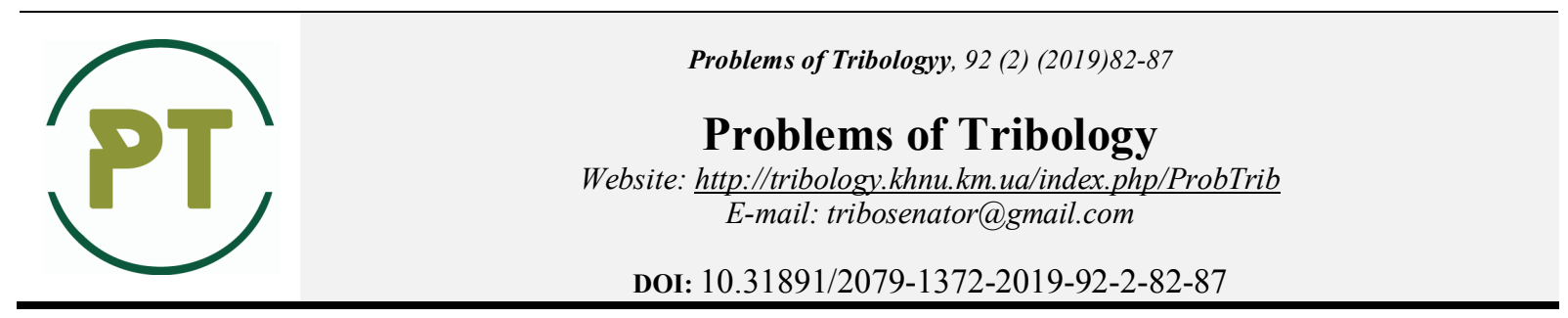

\title{
Investigation of wear of a contact pair of friction "rope block - rope"
}

\author{
D.D. Marchenko \\ Nikolaev national Agricultural University, Nikolaev, Ukraine \\ E-mail: marchenkodd@mnau.edu.ua
}

\begin{abstract}
Tribological studies conducted wear of the friction pair «cable block - rope», including rolling with sliding. It was found that wear does not depend on the hardness of the contacting surfaces at least by $5 \%$ slip. With the reduction of the surface roughness the coefficient of friction for the surfaces with grease decreases. It is shown that the slippage of up to $2 \%$, a sharp change in the coefficient of friction, after which it remains almost flat due to the spread of slip on the entire contact area. Bearing strain increases with increasing slip, if the shear stresses are sufficiently large.
\end{abstract} roller.

Key words: pair of friction, slipping, rolling motion, crumpling, coefficient of friction, rolling-off by a

\section{Introduction}

In the process of the contact interaction of bodies the state of the friction surfaces is influenced by many factors which should be considered when evaluating the options of trybological system on the point of identification of the processes and mechanisms of wear. The main factors are: physical and mechanical properties of materials and their interaction (hardness, structure, pressure, etc.), geometric properties of the contact surfaces of friction (deviation from form roughness that determine the speed of sliding friction behavior of friction pair, etc.) and environment of friction surfaces (temperature, humidity, presence of lubrication, etc.). Therefore, to elucidate the wear in the rolling considering slip is an important task for improving the durability tribotechnical characteristics of contacting surfaces, such as a friction pair «cable block - rope».

\section{Research methodology}

To determine the rate of wear in the slip the method for determining the rate of deterioration in variable contact area and in accordance with the contact pressure changes - the so-called method of holes was improved. In this method, the change of the area of trybological contact is achieved by the formation of holes of wear by a rotating disc or cylinder on the surface of the sample. Method of holes is used in Spindles, Konvisarova, SkodaSavin machinery according to standards ASTM G77-91, G83-90 and others. Usually when tested by this method durability rating is executed by volume, area or length of the chord holes wear obtained over time. This made it impossible to compare the wear resistance of materials, measured on machines with different disk size and shape of the sample.

In the process of the growth of the hole, the area of friction increases and reduces the rate of wear. Putting in accordance instantaneous contact pressure and instantaneous wear rate, we obtain the rate of wear curve depending on pressure [1].

To measure the depth of the hole the precise expensive equipment is necessary that can automatically take into account the disturbance made by heating, beating, changes in roughness, wear of disc. To measure the length of the hole, in many cases sufficient accuracy is $0,1 \mathrm{~mm}$, so these tests can be performed on almost any machine of friction. To calculate the rate of wear and building the graphs of wear rate of wear depends on the pressure source depending on the length of the hole on the way of rubbing or number of turns methodology of research was worked out by means of research methods.

For tests to determine tribotechnical characteristics used tribometer TRB - S - DE (Fig. 1), which was measured using such parameters as friction coefficient of accuracy $(0,01)$, the friction force, friction profilograph trace and conducted continuous measurements wear depth (profile trace) using dry friction in the presence of lu- 
bricants with automatic calculation of the rate of wear of working elements tribometer and sample tribological conjunction «drive - sector».

Special feature of this device is that the pin or flat surface area of the working element of tribometer is applied to the surface of the sample with the required load and angle and during the test is determined by the coefficient of friction due to elastic deflection lever of tribometer, and value the effort accurately measured. Vertical movement of the lever tribometer TRB $-\mathrm{S}-\mathrm{DE}$, controlled by special sensitive sensor in tests directly related to the depth point of contact wear. Also, the control parameters of such tests as rolling and sliding speed, frequency, contact press (in Hertz contact stress) as well as the parameters of time and environment (temperature, humidity and the presence or lack of lubrication) to simulate actual working conditions for working media on the wear of the material in real time.

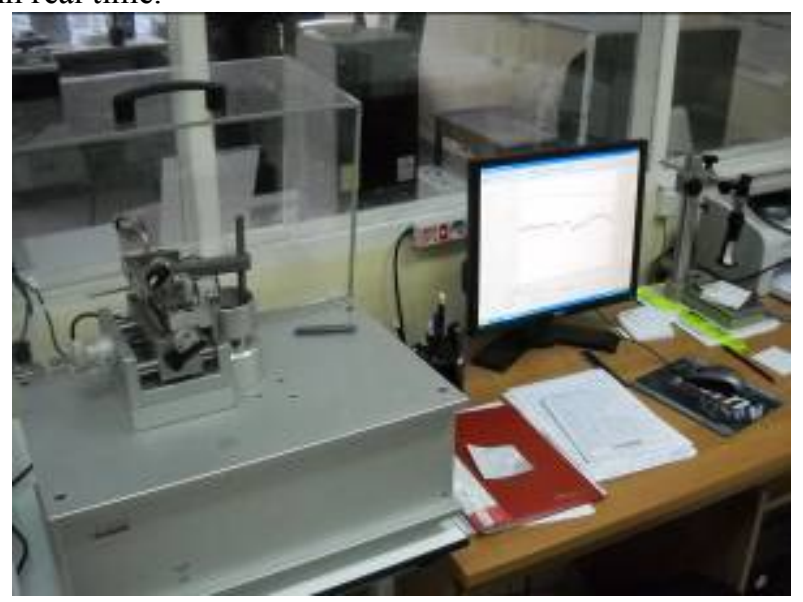

Fig. 1. Tribometer conjunction TRB - S - DE

The degree of wear of the samples (Fig. 2,a) was calculated by the software of tribometer, based on the volume of material lost during the study with a graphical display of the results (Fig. $2, b$ ).

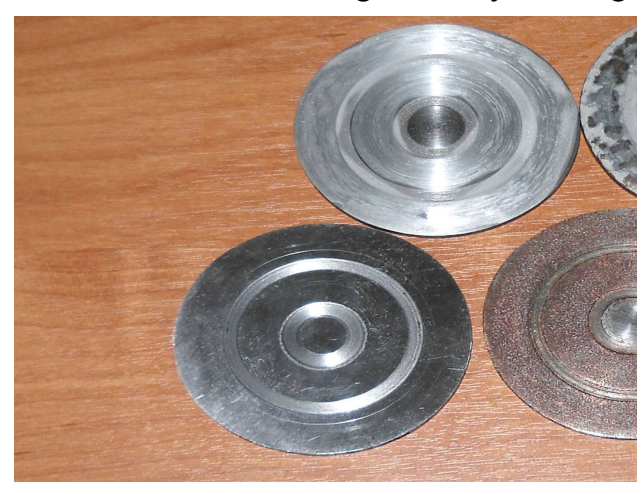

$a$

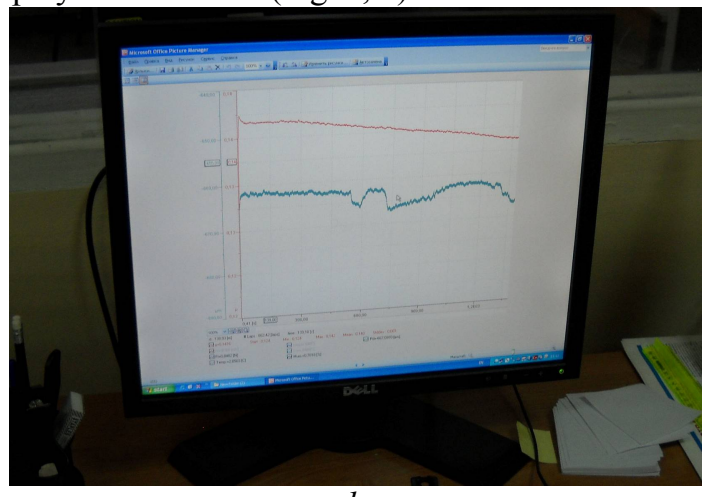

$b$

Fig. 2. Samples for tests $(a)$ and graphical representation of the results of research on tribometer TRB - S - DE (b)

Tests are conducted in accordance with DIN 50324, ASTM G99 «Standard Test Method for wear Testing with a Pin-on-Disk Apparatus», as well as standards ASTM G 133, ASTM D 3702, ASTM D 5183, ASTM D 4172 and ASTM D 2266.

Tests with constant friction factor have this advantage over some tests with constant slip: first, when tested with a constant factor change of the diameter of the samples was not greatly reflected in the slip, and secondly, the fall of the coefficient of friction in them when changing external conditions automatically compensated by an increase in slip and provides a more stable amount of wear rate than the tests that have maintained a constant slippage: an increase in humidity or air pollution in the latter case causes a decrease in the coefficient of friction and wear rate respectively [2].

The tests of the samples being rolled with the slip were conducted on a wear machine MI the top shaft of which was able to rotate, and was returned about a vertical axis at an angle of $5^{\circ}$, which provided lateral slip about $10 \%$ of that observed in the friction pair «cable block - rope». To measure the wear weight loss of samples used VLR - 200 .

\section{The results}

When using friction pair «cable block - rope» because of moving and inhibition longitudinal slip occurs, which is several times more than the cross.

Contact-fatigue damage of material at the contact interaction in real tribosystem can not only decrease with the increase of friction and respectively, equivalent stress, but may also increase. Fatigue damage of contact 
depends to a greater extent not only on the initial stress-strain state of contact, nor from the average stress-strain state, which is achieved by the time of appearing of contact fatigue crack but depends on heterogeneity of plastic deformation, which is created before the inception of contact-fatigue damage i.e. heterogeneity of residual stress field that is created in the contact fatigue until reaching the limit of slander $[3,4]$.

The speed of scrolling does not affect the results of determination of boundary-contact fatigue endurance. When rolling with longitudinal slip the leading and lagging rollers have different size of slip.

Likewise plays an important role in the mechanism of slip for internal or external rolling as contact pressure in this case is not defined by the Hertz formula (with internal rolling), then the method of equivalent pliability can be applied. Also there is difficulty in kinematics rolling with the flow balance in the tangent direction [5].

In the process of deterioration increases the size of the hole and the surface area of friction increases on the upper stationary roller, contact pressure is getting lower and thus the speed of wear. The coefficient of friction in the transition from sticking to the plastic smoothing of microscopic and then to oxidative deterioration vary very slightly, as determined by the critical pressure point sharp decrease in the rate of wear.

When the steel samples 20, 25L, 35L run-rollers, surface hardness HV 10 which was $235 \ldots 272$ were tested on the friction machine MI, the dependence of wear slip at different load was determined (Fig. 3).

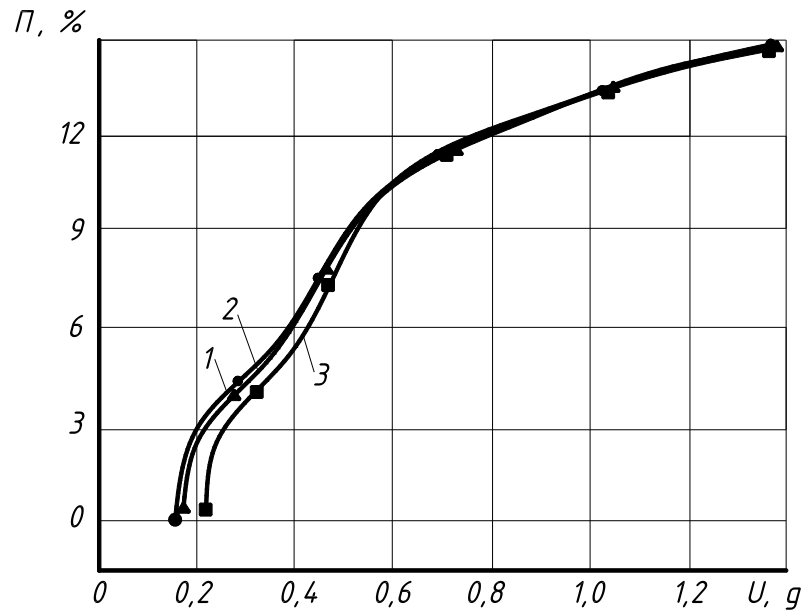

Fig. 3. Dependence of wear slip under load: $1-350$ H 2 - H $5003-650$ H

Found that wear actually depends on the load, but depends only on the slip.

In the case of rolling with longitudinal slip, equal to $10 \%$ of the friction surface become brown color, typical of oxidative deterioration. When cross-slip surface layer due to lateral plastic flow continuously updated. In longitudinal slip surface areas and products of wear, moving along the circle skating, interact repeatedly, increasing the role of corrosion during wear. Speed oxidative deterioration was dependent on the hardness of steel, so the impact of hardness on the results of experiments with longitudinal slip offset that should be considered when analyzing the results of a wear machine MI.

This was determined dependence of the rate of wear of the contact pressure in the simulation slip to $10 \%$ with samples of steel 35L run-roller, surface hardness HV 10 which was 232 (Fig. 4).

Thus, one could argue that the slip to $10 \%$ speed deterioration is almost independent of pressure or even decreases with its increase.

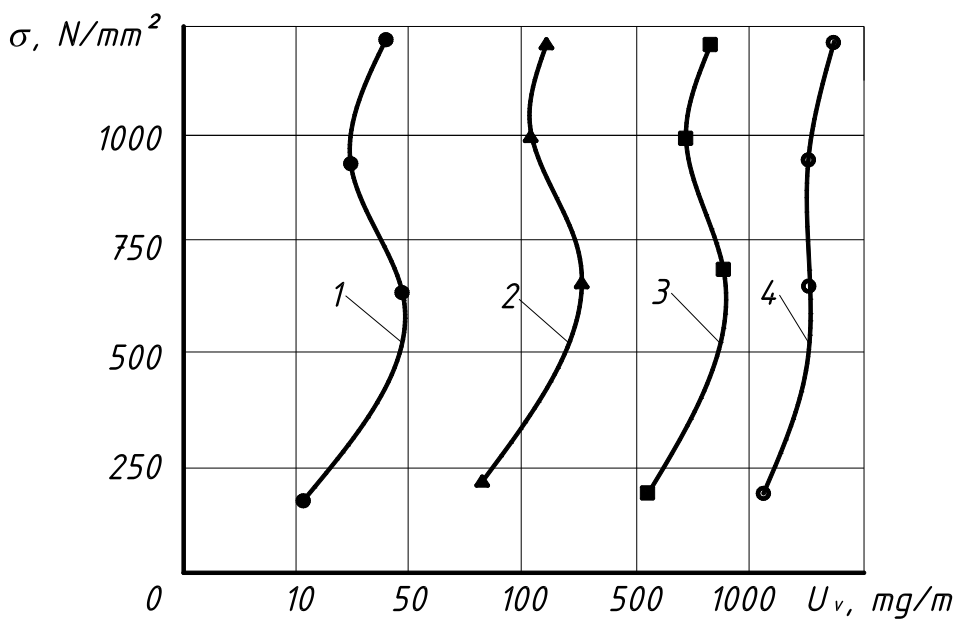

Fig. 4. Dependence of speed of wear on the pressure in contact with the sample of run steel 35L rolled in the process of modeling slip: $1-2,5 \% ; 2-5 \% ; 3-7,5 \% ; 4-10 \%$ 
When changing operating conditions tribosystem wear rate may change abruptly, thus changing the surface friction type, size, color and chemical composition of the products of friction, that is a result of the transition from one mechanism to the second wear.

Boundary layers of bodies or surface film, with their contact during the rolling of the sliding friction coefficient reduce to $3-4$ times and thus the speed and intensity of wear. Therefore, by changing the coefficient of friction may establish a process erase surface films.

Investigation of friction coefficient on the number of revolutions of samples of steel $34 \mathrm{HN} 1 \mathrm{M}$ conducted simulations slip to $10 \%$, with a load of $600 \mathrm{~N}$. In this case, the test samples were subjected to the running-in, surface hardness HV 10 which was 366, and after the break-roller with a force of $12 \mathrm{kN}$, surface hardness HV $10-$ 405 (Fig. 5). Lubrication samples occurred with the help of oil BOZ -1.

The experiments showed that the number of revolutions before the abrupt change in the coefficient of friction of the surface of film is uniformly distributed; this explains the steady value of friction coefficient, whose value is about 0,1 . When you reach a certain number of turns for the two samples without lubrication $(0,9$ $\cdot 10^{1} \mathrm{rpm}$. - for no run-sample and $50 \cdot 10^{1} \mathrm{rpm}$. - for a sample run-through video) boundary layers bodies begin to lose their properties change occurs multiple protective properties surface layer, which is why there is a sharp change in the coefficient of friction. It should be noted that the sample run-through video that change faster that fast run-in, then set the constant coefficient of friction, as is the balance of all processes (thermal, physical, mechanical, chemical), and the friction surface formed modified surface layers, which further define the mechanism of wear. The coefficient of friction is about the two samples without lubrication $0,45 \ldots 0,48$ and $0,2 \ldots 0,21$ and the second formation of a surface film with intense separation products wear appears. By means of rolling with break-rollers, which creates compressive residual stresses in the surface layer, lead to reduced separation of particles from the surface, thus reducing wear $[6,7]$. Similar results were obtained when testing specimens strengthened by car break-in method HZYP Skoda-Savin, as well as run-tested 45 samples of steel cut from the shaft, the test which was conducted on the wear on the spindle. According to these experiments, it can be argued that the compressive residual stresses arising from the from hindering wear [8].

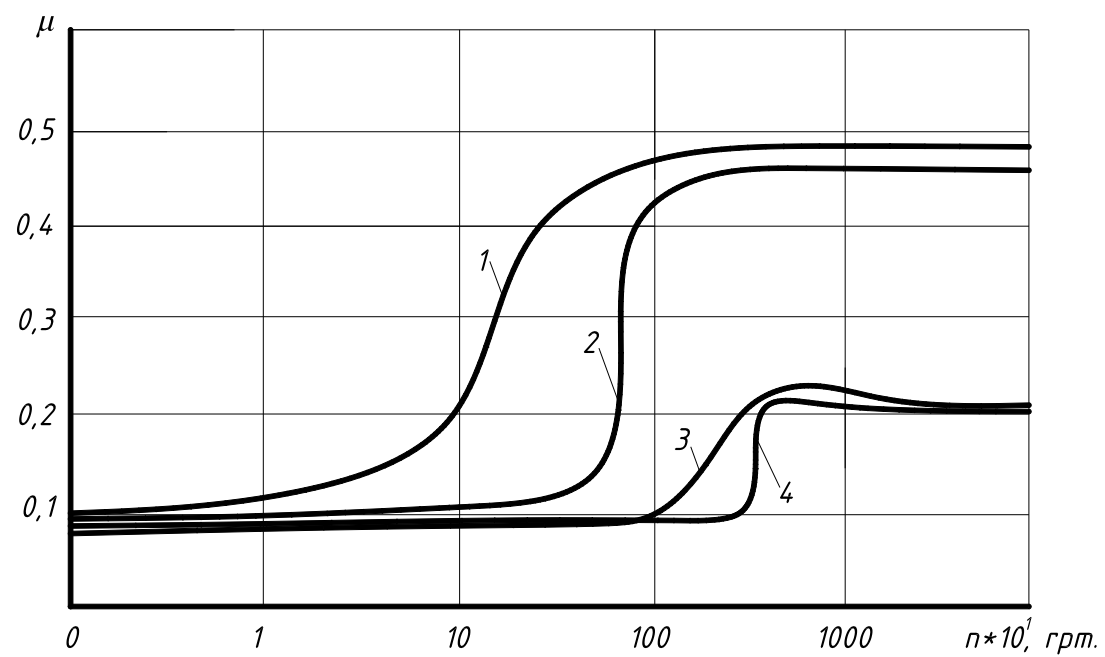

Fig. 5. Dependence of friction coefficient on the number of revolutions of samples of steel $34 \mathrm{HN} 1 \mathrm{M}$ from slipping to $10 \%$ : 1 - not run-sample without lubrication; 2 - sample run-through by roller without lubrication; 3 - not run-of lubrication; 4 - sample runthrough by roller with

Dependence of friction coefficient on the size of the slip was conducted on the samples before and after the break-in break-roller friction surface lubrication and without lubrication (Fig. 6). As oil used Torsyol - 55 (GOST $20458-75$ ), which is used for lubrication of cables, at the speed of rolling samples of $31,4 \mathrm{~m} / \mathrm{min}$., made of steel $35 \mathrm{~L}$.

As seen from the graph that the slip to $2 \%$ observed a drastic change in coefficient of friction, then it remains almost unchanged through the slip distribution on the entire contact area. The obvious connection maximum value of the friction coefficient of surface friction, as sudden changes in the coefficient of friction for reinforced and strengthened specimens with and without lubrication identified area (primed lines) when run-in is faster for samples run-rollers (Fig. 6), as can be argued that the surface roughness affects only at small slip (3\%). If slippage will not exceed $3 \%$, as observed in the work of the friction pair «cable block - rope» when presenting his break-roller will not be significant damage to the surface of contact, since the coefficient of friction is less than no break-roller.

Similar results were obtained when testing the wheel sets [1]. The author proved that increasing slip leads to an increase in work hardening of the surface layer decreases the surface roughness and friction, which reduces the crushing surface and thus wear surfaces. In our case, with break-roller [9-11], this effect is achieved faster, thus making the surface layer set tribotechnical properties with reduced rates of wear. 


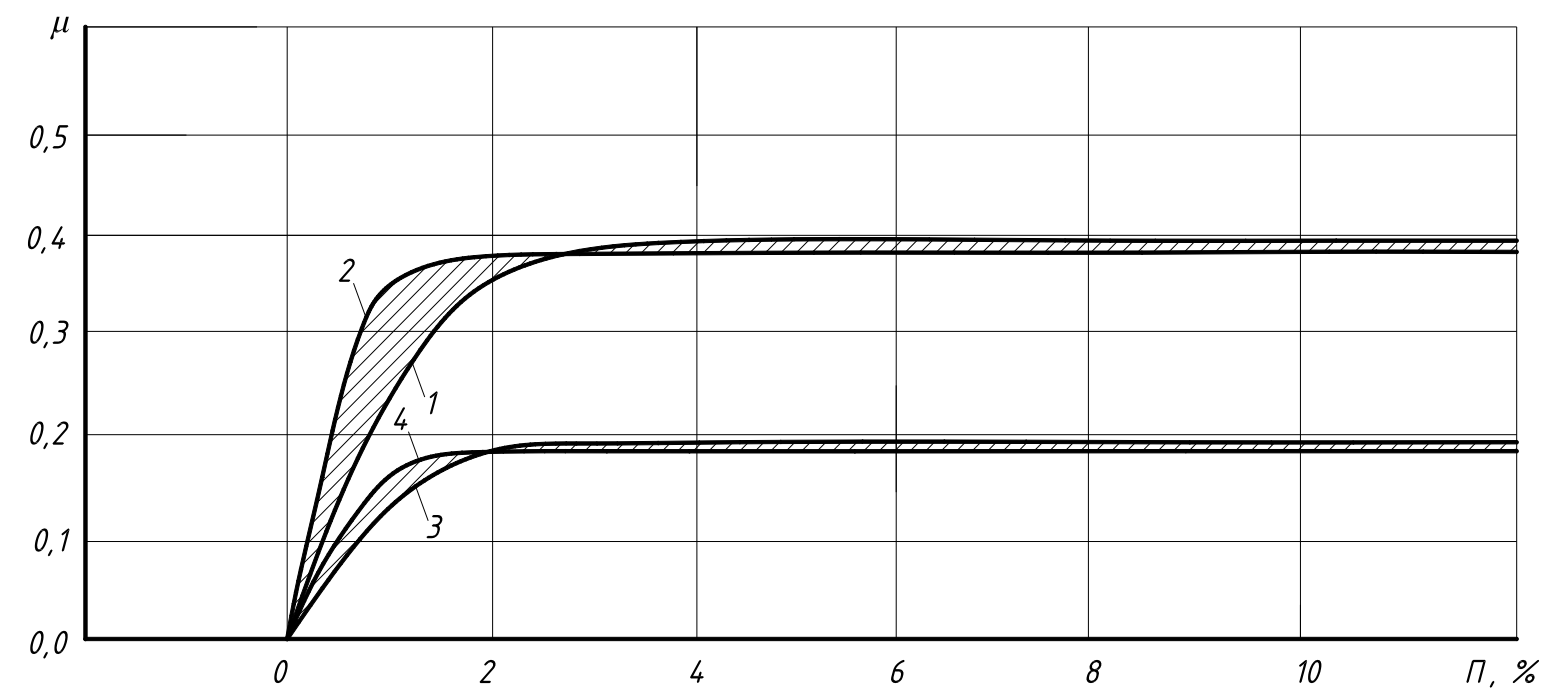

Fig. 6. Dependence of friction coefficient on the size of the slip: 1 - no run-sample without lubrication; 2 - sample run-through with the roller without lubrication; 3 - not run-of sample with lubrication; 4 - sample run-through with a roller with lubrication

Therefore, fig. 7 shows the dependence of the coefficient of friction of the surface roughness of the samples before and after the break-break-roller with grease lubrication Torsyol -55 .

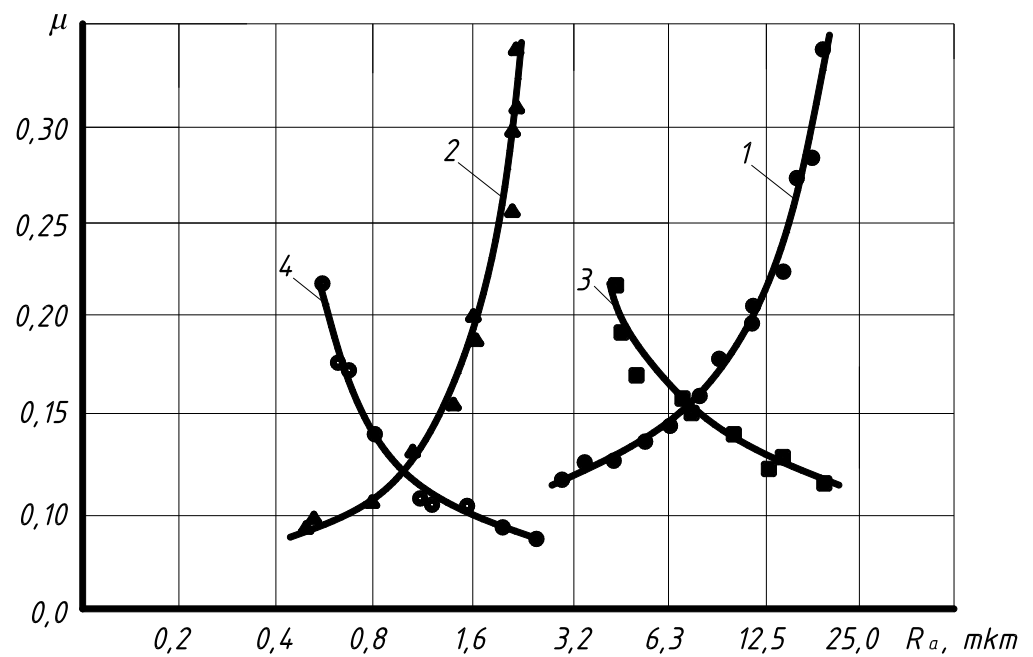

Fig. 7. The dependence of the coefficient of friction on roughness of surface: 1 - no run-sample without lubrication; 2 - sample runthrough with roller without lubrication; 3 - not run-of sample with lubrication; 4 - sample run-through with roller with lubrication

The graph shows that with the decrease of surface roughness the friction for samples that have lubrication is reduced.

\section{Conclusions}

1. In the process of contacting of surfaces with slip less than $5 \%$ the wear does not depend on surface hardness, but by changing the hardness of one of the surfaces of friction increased wear on other surfaces should be considered. Surface roughness effect on friction coefficient of friction and wear rate when rolling with slip, i.e. with decreasing surface roughness decreases.

2. If the slip is up to $2 \%$ it is seen as a sharp change in friction can be observed, after which it remains practically unchanged through the distribution of slip on the entire area of contact.

3. When rolling with a slip the main mechanisms is oxidative deterioration and jam wear. Deformation jam increases with increasing slip if tangent of pressure is rather large.

\section{References}

1. Markov D. P. Tribologicheskie aspekty povyshenija iznosostojkosti i kontaktno-ustalostnoj vynoslivosti koles podvizhnogo sostava: dis. ... doktora tehn. nauk : 05.02.04 / Markov Dmitrij Petrovich. — M., 1996. - $386 \mathrm{~s}$.

2. Bushe N. A. Sovmestimost' trushhihsja poverhnostej / N. A. Bushe, V. V. Kopyt'ko. - M. : Nauka, 1981. - $128 \mathrm{~s}$. 
3. Popov A. P. Kontaktnaja zadacha naprjazhenno-deformirovannogo sostojanija tel pri rabote stal'nogo kanatnogo bloka i trosa / A. P. Popov, B. I. Butakov, D. D. Marchenko // Problemi tribologiï. — Hmel'nic'kij, 2011. - № 1. - S. 29-36.

4. Marchenko D. D. Kincevo-elementne modeljuvannja kontaktnoi' vzajemodii' pry roboti stal'nyh kanatnogo bloku i kanatu / D. D. Marchenko // Problemy trybologii'. — Hmel'nyc'kyj, 2013. — № 1. — S. 86-93.

5. Kuz'menko A. G. Zakonomernosti proskal'zyvanija pri vnutrennem i naruzhnom kachenii cilindrov. Jeksperiment (Chast' 1) / A. G. Kuz'menko // Problemi tribologiï. — Hmel'nic'kij, 2012. — № 2. — S. 121126.

6. Butakov B. I. Povyshenie kontaktnoj prochnosti stal'nyh detalej obkatyvaniem ih rolikami / B. I. Butakov, D. D. Marchenko // Suchasni problemi tribologiï : mizhnar. nauk.-tehn. konf., 19-21 travnja 2010 r. : tezi dop. - K. : IVC ALKON NAN Ukraïni, 2010 - S. 74.

7. Butakov B. I. Razrabotka sposoba obkatyvanija rolikami stal'nyh detalej s cel'ju povyshenija ih kontaktnoj prochnosti / B. I. Butakov, D. D. Marchenko // MOTROL. Commission of Motorization and Power Industry in Agriculture Polish Academy of Sciences Branch of Lublin Ropczyce School of Engineering and Management. — Lublin, 2008. - Vol. 10V. - R. 15-28.

8. Shkol'nik L. M. Tehnologija i prisposoblenija dlja uprochnenija i otdelki detalej nakatyvaniem / L. M. Shkol'nik, V. I. Shahov. — M. : Mashinostroenie, 1964. — 184 s.

9. Butakov B. I. Povyshenie kontaktnoj prochnosti stal'nyh detalej s pomoshh'ju poverhnostnogo plasticheskogo deformirovanija / B. I. Butakov, D. D. Marchenko // Problemi tribologiï. — Hmel'nic'kij, 2008. — № 1. - S. $14-23$.

10. Issledovanie sostojanija poverhnostnogo sloja valov obkatannyh rolikami / B. I. Butakov, D. D. Marchenko, V. A. Artjuh, A. V. Zubehina // Tehnologii uprochnenija nanesenija pokrytij i remonta: teorija i praktika : materialy 14-j mezhdunar. nauch.-prakt. konf., 17 - 20 aprelja 2012 g. : tezisy dokl. : v 2 ch. — Sankt - Peterburg, 2012. - Ch. 2. - S. 50-64.

11. Pat. 93252 Ukrai'na, MPK V 24 V 39/04. Sposib chystovoi' ta zmicnjujuchoi' obrobky poverhon' til obertannja skladnogo profilju i prystrij dlja jogo zdijsnennja / B. I. Butakov, V. S. Shebanin, G. S. Butakova, D. D. Marchenko ; zajavnyk i patentovlasnyk Mykolai'vs'kyj derzhavnyj agrarnyj universytet. - № a200815098 ; zajavl. 29.12.2008; opubl. 12.07.2010, Bjul. № 13.

Марченко Д.Д. Исследование износа контактной пары трения «канатный блок - канат»

Проведены трибологические исследования изнашивания пары трения «канатный блок - канат» при качении с учетом проскальзывания. Было обнаружено, что изнашивание пары трения не зависит от твердости контактирующих поверхностей, с проскальзыванием менее 5\%. С уменьшением шероховатости поверхности коэффициент трения для поверхностей, которые имеют смазку, уменьшается. Показано, что проскальзывание до 2\% приводит к резкому изменению коэффициента трения, после чего он остается практически не изменённым из-за распространения скольжения на всю площадь контакта. Деформация смятия увеличивается, при повышении проскальзывания, если касательные напряжения достаточно велики.

Ключевые слова: пара трения, проскальзывание, качение, смятие, коэффициент трения, обкатывание роликом 